\title{
Multivariate analysis on performance in statistics, self-efficacy and attitudes of senior high school students
}

\author{
Mildin Jimenez Retutas ${ }^{1 *}$, Marilyn Torela Rubio ${ }^{2}$ \\ ${ }^{1}$ College of Teacher Education and Technology, University of Southeastern Philippines, Philippines \\ ${ }^{2}$ College of Education, Bukidnon State University, Philippines \\ *Corresponding author: mj.retutas@usep.edu.ph
}

\section{ARTICLE INFO}

Article history:

Received: 6 May 2021

Revised: 21 June 2021

Accepted: 22 June 2021

Published online: 26 October

2021

Published regularly: October 2021

\section{ABSTRACT}

Over the past few years, teaching and learning of statistics have been influenced by the emergence of the reform movement in education such as the $\mathrm{K}-12$ basic education curriculum. Those of statistics concepts have changed both elementary and secondary level. Considering the educational reform in the Philippines, the study was conducted to determine whether there are significant differences of the determinants such as gender, type of school, parent's educational level, family monthly income, family size and Senior High School track preference to students' self-efficacy beliefs, attitudes towards Statistics, and performance in Statistics. The causal-comparative research design was used for comparing two or more groups to find the differences or determine whether the independent variable influences the dependent variable. The data were gathered from 570 senior high school students of both public and private schools in Mindanao, Region XI. The study adopted the questionnaires on self-efficacy beliefs and attitude towards Statistics while it utilized a researcher-made questionnaire for performance in Statistics. Multivariate Analysis of Variance (MANOVA) was used to determine whether multiple levels of independent variables on their own or in combination with one another influence the dependent variables. The findings revealed that among the demographic factors, only type of school has a significant difference to the self-efficacy beliefs, attitudes towards Statistics, and performance of senior high students in Statistics. Implications from the findings of this study might suggest that improving of K-12 school facilities by the school public administrators and collaborative effort of teachers to enhance the students' self-efficacy, attitudes towards statistics and teaching statistics reveals optimistic results. Also, school administrators may provide opportunities for Statistics teachers to hone their pedagogical skills in promoting and building students' self-confidence and interest in the subject.

(C) 2021 Universitas Muhammadiyah Surakarta

\section{Introduction}

Mathematics has been viewed as one of the difficult subjects to learn and teach in elementary, junior, and senior high schools. Students' mathematics performance has been consistently low in comparison to different subjects within the curricula. From the national 
level down to the school level, different methods were utilized to address the factors that contribute to the decline of student's performance (Zacal, 2019).

In the K-12 Statistics curriculum, one of the core subjects offered in the senior high school is statistics and probability. Elements of statistics and probability reasoning have emerged as requisite for a wide variety of applications especially in research in all fields of endeavors. Thus, without enough foundation of the essential ideas to understand data, readers are left confused. As mentioned in the study of Chiesi, Pirmi, and Morsanyi (2010), many students find it hard to understand statistics and probability concepts as documented in the different educational contexts and it is perhaps true to all secondary and tertiary students. For this reason, to better understand the underlying mechanism of statistics achievement, more attention has been paid to student's beliefs and feelings about statistics, and focused on the identification of models with non cognitive factors such as beliefs and feeling about statistics (Zieffer, et.al., $\underline{2008}$ as cited by Chiesi, Pirmi, and Morsanyi, 2010).

As mentioned by Batanero and Diaz (2010), statistics is becoming increasingly important in modern society; the relevance of developing statistical thinking in students across all levels of education has grown. Statistics is offered in secondary education. Unfortunately, many students fail to recognize its importance (Peters, Smith, Middledorp, Karpin, Sin, \& Kilgore, 2013). In order for students to succeed and to use statistics, they should think that statistics is valuable in their lives (Emmioglu \& Capa-Aydin, 2012).

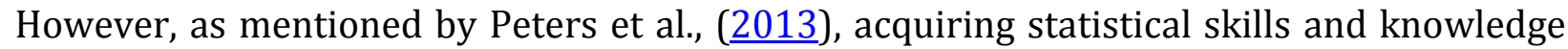
poses significant challenges for many students; a statistics course is challenging because it is abstract and requires logical reasoning, critical thinking, and the skills of interpretation and drawing conclusions. In addition, since teaching Statistics is integrative to secondary year levels, some students find it difficult to understand especially statistics (Salvan, 2014). Also, when it comes to rational number concepts and proportional reasoning, most of the students have an underlying difficulty necessary for calculating, reporting, and interpreting probabilities (Doyle et al., 2015). These are confirmed by Hansen and Myers (2012) also reported students to have low percentages of correct responses.

In addition, before the implementation of the current curriculum, students typically have an inadequate background in statistics before they enter college (Lemana, 2012). There was, however, the introduction of the concepts of statistics and probability have vigorously growing movement into the secondary school curriculum as basic literacy in statistics and probability, that mandates all citizens in today's world to have (Swift, 2012). Although the K-12 curriculum provides the concepts in statistics and probability and teaches these concepts from Grades 1 to 8 and in Grade 10, the depth at which learners absorb and fully grasp them may need reinforcement and consideration (Salvan, 2014).

In the Philippine educational system, statistics and probability ideas frequently seem to struggle in students' experiences and how they perceive the world (Herrera, 2011). Most of the students have developed a distance of learning statistics and probability in the most concrete way. For this reason, Prado and Gravoso (2011) cautioned teachers to introduce topics not by abstractions but through activities and simulations.

In the Division of Davao City, the integration of statistics and probability as one of the subjects taught in senior high school has brought concerns but also to the students as well. This concern has rooted in the fact that the majority of the teachers who are assigned to teach this subject had no formal training in statistics and probability and some other factors contributing to the low students' performance include parents, teachers, and schools (Jamisola, 2014). Nevertheless, teachers with or without enough preparations are 
required to be competent and knowledgeable in presenting and developing the topics (Salvan, 2014).

Moreover, Bakhshalizadeh, Pasha and Rastgar (2011) stated that mathematics has a close relationship with statistics in a manner and statistics is the scientific application of mathematical basics for the collection, analysis, and presentation of numerical data. Therefore, learning mathematics helps a lot to learn and succeed in statistics. Thus, different factors could influence Statistics performance in statistics. The study of Chapagain (2021) has identified socio-demographic and student-related factors such as type of school, type of local government, nature of examination, gender, age, and ethnicity that influence students' academic performance. In addition, parent's education, family income, and family size are some of the variables to be included.

Students' attitudes toward statistics are prevalent. To this, Chinn (2012) supports those bad experiences in statistics specifically in learning statistics, math anxiety, and lack of support from adults may have caused the negative culture around Statistics. Furthermore, as mentioned by McGrath et al. (2015), to be successful in their statistics courses, students must possess high levels of self-efficacy. According to Bandura (1986), having high self-efficacy helps students to feel that they can develop the skills they need to master a given concept, even if they have to work through setbacks. These beliefs, in turn, prompt students to engage in effective studying and learning behaviors. Other researchers have similarly found self-efficacy to be a significant predictor of course performance in statistics (Byrne et al., 2014; McGrath et al., 2015).

Similarly, as mentioned in the study of Huynh, Baglin, and Bedford (2014), in statistics education, there exists a consistent positive relationship between statistics attitudes and achievement. Improving student's attitudes towards statistics and statistics remains a challenging task with many students finding the subjects uninteresting, difficult, and tedious. According to Murray (2011), there are reasons for the decline in students taking statistics as subjects in high school. There is a need to improve student's attitudes towards quantitative subjects like statistics. Furthermore, improving student's attitudes in statistics in secondary school may lead to improved tertiary and career pathways into mathematical and statistical disciplines.

Junior and senior high school students have been noted to have low performance in statistics and probability (Zacal, 2014). With this, it is very imperative to identify those factors leading to students' low performances in statistics. Thus, educational authorities adopt some policies improving the students' performance.

Moreover, there is still a lack of studies investigating factors affecting students' selfefficacy, attitude change towards statistics, and performance in statistics, particularly at the secondary school level. This research aims to examine the multivariate effects of determinants such as gender, type of school, parent's educational level, family size, family monthly income, and SHS track preference to the self-efficacy, attitudes toward statistics, and performance in statistics of senior high school students. The result of this study would help students understand their weaknesses in learning statistics. They would also recognize that their self-efficacy and attitudes towards statistics are affected by several factors. Their recognition of some elements would stimulate their interest to learn the subjects and develop favorable attitudes towards the subject amidst adversities. Moreover, the findings would provide information to secondary institutions for possible consideration of looking into the appropriate intervention program in reinforcing student's difficulties in learning statistics. Thus, it may provide insights to the teachers into what factors might contribute to the enhancement of their performance towards the subject. Furthermore, the result of this study would provide relevant information to mathematics 
teachers on how to come up with varied learning activities that would address student's difficulties in learning the lesson and develop positive attitudes and sense of fulfillment towards the subject. The result would be of great help for the teachers to revisit and strengthen their delivery of instruction that would later stimulate learning on the part of the student. Lastly, the study would serve as reference material in particular for researchers who plan to use MANOVA for future studies of other variables.

Specifically, this study answered the following research objectives. First, to determine the level of the three dependent variables namely student's self-efficacy beliefs, attitudes towards statistics and performance in statistics. Second, to determine the test of difference in student's self-efficacy beliefs, attitudes towards statistics, and performance in statistics when grouped according to the determinants. Lastly, to identify which of the determinants significantly affect the three dependent variables.

\section{Research Methods}

\section{Research design}

This study is quantitative research, employing descriptive causal-comparative research design. The causal-comparative research design is the best approach to be used for comparing two or more groups to find the differences or determine whether the independent variable influences dependent variable (Gray et al., 2011; Yilmaz, 2013; Hussain, 2019). This design provides appropriate evidence of the differences and the level of significance of variables as well as the statistical analysis of the influence attributed by the independent variables to the dependent variables (Arghode, 2012 \& Yilmaz, 2013).

Moreover, in the causal-comparative research, the correspondents examine how the independent variables affect the dependent variables and involve cause and effect relationship (Williams, 2014). In this study, the correspondents determined how the independent variables affect the dependent variables - gender, family monthly income, family size, parent's educational level, SHS track preference, type of schools and selfefficacy beliefs, attitudes towards Statistics and performance in Statistics, respectively.

\section{Research locale}

The study was conducted in the selected private and public senior high schools in Region XI, Mindanao. Baseline data on SHS track and strands offerings across the region were utilized. These secondary high schools in Region XI offer Academic Track and Technology and Vocational Livelihood (TVL) track in the SHS department.

\section{Sampling design}

A random sampling technique was used for selecting the respondents of the study; a type of probability sampling in which the author randomly selects a subset of participants from a population, and each member of the population has an equal chance of being selected. The participants of this study were the senior high school students enrolled in private and public secondary schools in Region XI, Mindanao. These students have enrolled in Academic and Technical Vocational and Livelihood (TVL) tracks. A total sample of 570 was utilized in the study where 315 students came from public schools and 255 students from private schools.

\section{Data gathering procedure}

First, the endorsement letter to conduct the study was secured. After receiving the endorsement letter, the researcher sought permission from the schools division superintendent for the conduct of the study. Upon approval, the correspondents sent a letter to the different principals and school heads of the selected schools. 
The researcher gathered the data at different times at different schools. The researcher, with the assistance of the focal person, personally explained and administered the questionnaires to the participants. They answered the three instruments starting on the self-efficacy beliefs, attitudes toward statistics and followed by the achievement test in statistics. Before the administration, respondents were oriented and informed about the study.

There were three instruments employed to gather the data. These include the following: self-efficacy survey questionnaire, attitudes toward statistics survey questionnaire, and achievement test in statistics. Survey questionnaires for self-efficacy beliefs and attitudes toward statistics were all adopted, while the achievement test in statistics was constructed based on the competencies of the grade 11 curriculum level. The self-efficacy survey questionnaire was adopted from Salvan (2016) with a Cronbach alpha of 0.821. This questionnaire was utilized to identify the level of self-efficacy beliefs of senior high school students. The attitudes toward statistics survey questionnaire were adapted from Orongan (2007) with a Cronbach alpha of 0.91 . The instrument is composed of 47 items with five responses using the 5-point Likert scale. It measures four indicators of attitude, namely: 1) personal confidence about the subject; 2) usefulness of the subject's content; 3) subject is perceived as a male domain; and 4) perception of teacher's attitudes. The achievement for statistics was validated before its administration, composing of a senior high school master teacher, a senior high school focal person, and a college professor who were teaching statistics and probability subject. The test underwent revisions based on their comments and suggestions. The instrument was found to have a Cronbach alpha of 0.86 .

\section{Data analysis}

To facilitate the analysis of data, the mean, standard deviation, Box's M, Levene's test and Multivariate Analysis of Variance (MANOVA) were used. The study made use of a fivepoint Likert scale. According to Boone (2012), Likert-scale data re analyzed at the interval measurement scale and are created by calculating a composite score (sum or mean) from four or more type Likert-type items; therefore, the composite score should be analyzed at the interval measurement scale. Descriptive statistics recommended for interval scale items include the mean for central tendency and standard deviations for variability.

The mean and SD were utilized to determine the level of self-efficacy beliefs, attitudes toward statistics, and performance in statistics of senior high school students. The Box's M and Levene's test were used to determine the normality and homogeneity of the data before testing the significant difference. MANOVA was employed to determine the difference between the independent and dependent variables and which of the determinants significantly affects the dependent variables.

\section{Results and Discussion}

Level of self-efficacy beliefs, attitudes towards statistics and performance in statistics of senior high school students

Table 1 shows the grade 11 students' level of self-efficacy beliefs, attitudes towards Statistics and performance in Statistics. It can be gleaned in Table 1 that the self-efficacy beliefs of the students were described as neither agree nor disagree/undecided. This datum means that students have inhibited confidence in solving Statistical problem. It further implies that grade 11 students are uncertain whether or not he/she is favorable or unfavorable in believing that they have enough confidence in doing statistical tasks and 
solving statistical problems. The findings explain that efforts are necessary to promote selfefficacy for high school students as it is closely associated with statistics achievement.

Table 1

Level of self-efficacy beliefs, attitudes towards statistics and performance in statistics of senior high school students

\begin{tabular}{lccl}
\hline Dependent Variables & Mean & SD & Qualitative Description \\
\hline Self-Efficacy Beliefs & 3.07 & 0.41 & Undecided \\
Attitude towards Statistics & 3.08 & 0.23 & Undecided \\
Performance in Statistics & 78.89 & 3.51 & Fairly Satisfactory \\
\hline
\end{tabular}

The result of this study is in consonance with the study of Schneider (2011) stated that self-efficacy is the level of student's confidence to perform specific statistics related tasks under specific conditions or situations. Students feel less anxious when their selfefficacy is high, and they become more motivated and determined to succeed. Students who are confident enough in communicating and relating to another individual are likely to succeed. When they are confident, they perform better and are expected to have better grades in examinations.

In addition, the overall result on students' attitudes toward statistics implies that attitude influences a person's emotional nature which eventually has an impact on the behavior of individuals. If the students' attitude toward statistics is positive, their achievement is likely to increase. If it is negative, their achievement in statistics tends to decrease. More importantly, they learn best if they find learning the subject useful, enjoyable and exciting.

As Jamisola (2014) established, attitude is one of the factors that contribute a lot to the success or failure of students in doing non-routine mathematical problem-solving. Students who are statistics enthusiasts and have a positive attitude toward the subject are much seen to perform successfully in solving a problem. Also, they tend to make their way of solving a problem more than ones introduced by the teacher. The result of this present study lends support to Tan's contention.

Furthermore, the overall mean percentage score of the students' performance is fairly satisfactory. Such finding means that most of the students demonstrate low level of performance. Thus, students possess the minimum knowledge and skills and core understanding, but they need help throughout the performance tasks. This detail further implies that the students on these levels have developed and grasped the required knowledge and understandings and can transfer it dependently throughout authentic performance tasks (DepEd Order No. 8, s. 2015). This finding supports the study of Hansen and Myers (2012) that there are students who have low percentages of correct responses in understanding the underlying statistical principles.

\section{Multivariate test according to gender}

Table 2 reflects the summary of MANOVA results across gender. The Table 2 shows that $p$-value indicates that there is a significant difference in gender between male and female in measuring attitudes toward statistics. Either male or female is more likely to feel anxious when working on statistics; students are more likely to say that she/he did not enjoy statistics and found it stressful; and student is less likely to find statistics exciting, likable, or name it as one of his/her favorite activities. It is clear that there is a tendency for males or females to have more positive attitudes toward statistics. This finding conforms to the finding in the study of Gherasim, Butnaru, and Mairean ( $\underline{2013}$ ) who determined that gender outcomes in such variables as achievement goals, lecture room environments and 
achievement in statistics teenagers, reveal that females obtained better in statistics than males.

Table 2

Summary of MANOVA results across gender

\begin{tabular}{|c|c|c|c|c|c|c|c|}
\hline $\begin{array}{c}\text { Independent } \\
\text { Variables } \\
\end{array}$ & Dependent Variables & $\begin{array}{l}\text { Type III Sum } \\
\text { of Squares }\end{array}$ & Df & Mean Square & $\mathrm{F}$ & Sig. & $\begin{array}{c}\text { Partial Eta } \\
\text { Squared }\end{array}$ \\
\hline \multirow{3}{*}{$\begin{array}{l}\text { Corrected } \\
\text { Model }\end{array}$} & Self-Efficacy Beliefs & $0.007^{a}$ & 1 & 0.007 & 0.032 & 0.859 & 0.000 \\
\hline & $\begin{array}{l}\text { Attitudes toward } \\
\text { Statistics }\end{array}$ & $1.092^{\mathrm{b}}$ & 1 & 1.092 & 9.594 & 0.002 & 0.017 \\
\hline & $\begin{array}{l}\text { Performance in } \\
\text { Statistics }\end{array}$ & $0.666^{c}$ & 1 & 0.666 & 0.054 & 0.816 & 0.000 \\
\hline \multirow{3}{*}{ Intercept } & Self-Efficacy Beliefs & 5037.65 & 1 & 5037.65 & 21946.84 & 0.000 & 0.975 \\
\hline & $\begin{array}{l}\text { Attitudes toward } \\
\text { Statistics }\end{array}$ & 6232.13 & 1 & 6232.13 & 54762.85 & 0.000 & 0.990 \\
\hline & $\begin{array}{l}\text { Performance in } \\
\text { Statistics }\end{array}$ & 3545680.52 & 1 & 3545680.53 & 287500.53 & 0.000 & 0.998 \\
\hline \multirow{3}{*}{ Gender } & Self-Efficacy Beliefs & 0.007 & 1 & 0.007 & 0.032 & 0.859 & 0.000 \\
\hline & $\begin{array}{l}\text { Attitudes toward } \\
\text { Statistics }\end{array}$ & 1.092 & 1 & 1.092 & 9.594 & 0.002 & 0.017 \\
\hline & $\begin{array}{l}\text { Performance in } \\
\text { Statistics }\end{array}$ & 0.666 & 1 & 0.666 & 0.054 & 0.816 & 0.000 \\
\hline \multirow{3}{*}{ Error } & Self-Efficacy Beliefs & 130.38 & 568 & 0.230 & & & \\
\hline & $\begin{array}{l}\text { Attitudes toward } \\
\text { Statistics }\end{array}$ & 64.64 & 568 & 0.114 & & & \\
\hline & $\begin{array}{l}\text { Performance in } \\
\text { Statistics }\end{array}$ & 7005.02 & 568 & 12.333 & & & \\
\hline \multirow{3}{*}{ Total } & Self-Efficacy Beliefs & 5170.78 & 570 & & & & \\
\hline & $\begin{array}{l}\text { Attitudes toward } \\
\text { Statistics }\end{array}$ & 6305.68 & 570 & & & & \\
\hline & $\begin{array}{c}\text { Performance in } \\
\text { Statistics }\end{array}$ & 3554902.00 & 570 & & & & \\
\hline
\end{tabular}

Furthermore, the performance of the students, both male and female, in statistics and probability is not significant. They demonstrate a low level of performance, expecting that females perform as well as men. Since both are of the same level of performance, they can excel in statistics. This datum proves that the performance of the students in statistics has nothing to with gender. The study conducted by Ajai and Imoko (2015) stated that boys have the same mathematical ability with girls for they found out that both male and female students' achievement in algebra does not significantly differ since both of them performed better in statistics.

Also, this study confirms the finding of Asante (2012) that male students are more enthusiastic about statistics than female students. Male students show more eagerness to learn statistics than female ones. About emotions toward statistics, girls found less enjoyment and pride than boys. They also felt ashamed more slightly than the boys. The boys, on the other hand, were anxious and hopeless toward statistics. Moreover, Ali (2013) mentioned that the students' gender does not directly affect their performance in statistics.

\section{Multivariate test according to family monthly income}

Table 3 reports the test of difference by family monthly income across the three dependent variables. The $p$-value indicates no significant difference between the family 
monthly income in terms of students' self-efficacy, attitudes toward statistics, and performance in statistics.

Table 3

Summary of MANOVA results across family monthly income

\begin{tabular}{|c|c|c|c|c|c|c|c|}
\hline $\begin{array}{c}\text { Independent } \\
\text { Variables }\end{array}$ & Dependent Variables & $\begin{array}{c}\text { Type III Sum } \\
\text { of Squares }\end{array}$ & $\overline{\mathrm{Df}}$ & Mean Square & $\mathrm{F}$ & Sig. & $\begin{array}{c}\text { Partial Eta } \\
\text { Squared }\end{array}$ \\
\hline \multirow{3}{*}{$\begin{array}{l}\text { Corrected } \\
\text { Model }\end{array}$} & Self-Efficacy Beliefs & $0.056^{\mathrm{a}}$ & 2 & 0.028 & 0.122 & 0.886 & 0.000 \\
\hline & $\begin{array}{l}\text { Attitudes toward } \\
\text { Statistics }\end{array}$ & $0.298^{b}$ & 2 & 0.149 & 1.290 & 0.276 & 0.005 \\
\hline & $\begin{array}{l}\text { Performance in } \\
\text { Statistics }\end{array}$ & $5.569^{c}$ & 2 & 2.785 & 0.226 & 0.798 & 0.001 \\
\hline \multirow{3}{*}{ Intercept } & Self-Efficacy Beliefs & 1794.58 & 1 & 1794.58 & 7807.37 & 0.000 & 0.932 \\
\hline & $\begin{array}{l}\text { Attitudes toward } \\
\text { Statistics }\end{array}$ & 2211.28 & 1 & 2211.28 & 19161.31 & 0.000 & 0.971 \\
\hline & $\begin{array}{l}\text { Performance in } \\
\text { Statistics }\end{array}$ & 1252135.39 & 1 & 1252135.39 & 101421.30 & 0.000 & 0.994 \\
\hline \multirow{3}{*}{$\begin{array}{l}\text { Family } \\
\text { Monthly } \\
\text { Income }\end{array}$} & Self-Efficacy Beliefs & 0.056 & 2 & 0.028 & 0.122 & 0.886 & 0.000 \\
\hline & $\begin{array}{l}\text { Attitudes toward } \\
\text { Statistics }\end{array}$ & 0.298 & 2 & 0.149 & 1.290 & 0.276 & 0.005 \\
\hline & $\begin{array}{l}\text { Performance in } \\
\text { Statistics }\end{array}$ & 5.57 & 2 & 2.785 & 0.226 & 0.798 & 0.001 \\
\hline \multirow{3}{*}{ Error } & Self-Efficacy Beliefs & 130.33 & 567 & 0.230 & & & \\
\hline & $\begin{array}{l}\text { Attitudes toward } \\
\text { Statistics }\end{array}$ & 65.43 & 567 & 0.115 & & & \\
\hline & $\begin{array}{l}\text { Performance in } \\
\text { Statistics }\end{array}$ & 7000.12 & 567 & 12.346 & & & \\
\hline \multirow{3}{*}{ Total } & Self-Efficacy Beliefs & 5170.78 & 570 & & & & \\
\hline & $\begin{array}{l}\text { Attitudes toward } \\
\text { Statistics }\end{array}$ & 6305.68 & 570 & & & & \\
\hline & $\begin{array}{c}\text { Performance in } \\
\text { Statistics }\end{array}$ & 3554902.00 & 570 & & & & \\
\hline
\end{tabular}

The family monthly income has no impact on the self-efficacy beliefs, attitudes toward statistics, and performance of senior high students in statistics and probability. Students manifest low performance in the subject despite of the family income of their parents. The family monthly income has nothing to do with their performance in the school.

However, this result contradicts Humlum's (2011) finding that the family income, high or low, can have an impact on students' performance in their entire learning years. The result further specifies that family income can affect education in the early years. Likewise, Reardon (2013) represents how students from families with high income are having best performance than low-income families' students. The impact of the income can be shown in the early of the student's learning and showed better results to the student's academic achievement. In addition, students from high income have the opportunity to get in any colleges or universities than others.

\section{Multivariate test according to family size}

Table 4 shows the test of significant difference by family size across the three dependent variables. The $p$-values indicate that there is no significant difference between parents' educational level in terms of students' elf-efficacy beliefs, attitudes toward statistics, and performance in statistics. 
Table 4

Summary of MANOVA results across Family Size

\begin{tabular}{|c|c|c|c|c|c|c|c|}
\hline $\begin{array}{l}\text { Independent } \\
\text { Variables }\end{array}$ & Dependent Variables & $\begin{array}{c}\text { Type III Sum } \\
\text { of Squares }\end{array}$ & Df & Mean Square & $\mathrm{F}$ & Sig. & $\begin{array}{c}\text { Partial Eta } \\
\text { Squared }\end{array}$ \\
\hline \multirow{3}{*}{$\begin{array}{l}\text { Corrected } \\
\text { Model }\end{array}$} & Self-Efficacy Beliefs & $0.202^{\mathrm{a}}$ & 2 & 0.101 & 0.439 & 0.645 & 0.002 \\
\hline & $\begin{array}{l}\text { Attitudes toward } \\
\text { Statistics }\end{array}$ & $0.467 \mathrm{~b}$ & 2 & 0.233 & 2.027 & 0.133 & 0.007 \\
\hline & $\begin{array}{l}\text { Performance in } \\
\text { Statistics }\end{array}$ & $19.362^{c}$ & 2 & 9.681 & 0.786 & 0.456 & 0.003 \\
\hline \multirow{3}{*}{ Intercept } & Self-Efficacy Beliefs & 4868.57 & 1 & 4868.57 & 21204.48 & 0.000 & 0.974 \\
\hline & $\begin{array}{l}\text { Attitudes toward } \\
\text { Statistics }\end{array}$ & 6015.02 & 1 & 6015.02 & 52256.63 & 0.000 & 0.989 \\
\hline & $\begin{array}{l}\text { Performance in } \\
\text { Statistics }\end{array}$ & 3419841.73 & 1 & 3419841.73 & 277549.50 & 0.000 & 0.998 \\
\hline \multirow{3}{*}{ Family Size } & Self-Efficacy Beliefs & 0.202 & 2 & 0.101 & 0.439 & 0.645 & 0.002 \\
\hline & $\begin{array}{l}\text { Attitudes toward } \\
\text { Statistics }\end{array}$ & 0.467 & 2 & 0.233 & 2.027 & 0.133 & 0.007 \\
\hline & $\begin{array}{l}\text { Performance in } \\
\text { Statistics }\end{array}$ & 19.36 & 2 & 9.68 & 0.786 & 0.456 & 0.003 \\
\hline \multirow{3}{*}{ Error } & Self-Efficacy Beliefs & 130.18 & 567 & 0.230 & & & \\
\hline & $\begin{array}{l}\text { Attitudes toward } \\
\text { Statistics }\end{array}$ & 65.27 & 567 & 0.115 & & & \\
\hline & $\begin{array}{l}\text { Performance in } \\
\text { Statistics }\end{array}$ & 6986.32 & 567 & 12.322 & & & \\
\hline \multirow{3}{*}{ Total } & Self-Efficacy Beliefs & 5170.78 & 570 & & & & \\
\hline & $\begin{array}{l}\text { Attitudes toward } \\
\text { Statistics }\end{array}$ & 6305.68 & 570 & & & & \\
\hline & $\begin{array}{l}\text { Performance in } \\
\text { Statistics }\end{array}$ & 3554902.00 & 570 & & & & \\
\hline
\end{tabular}

When it comes to self-efficacy, the family size does not influence the attitudes toward statistics and performance in statistics. Students' performance in statistics has nothing to do across family siblings and with the number of children in the family. Thus, the students have low performance regardless of the number of siblings.

However, this result contradicts the statement that the number of siblings in the family is related to the higher academic achievement of the students. With fewer siblings, the students can have more parental attention and more access to resources than those who belong to bigger families. Therefore, family size has some effects on the academic performance of students. Lacovou (2010) stated that later-born children perform lesser than the earlier-born siblings because parental attention decreases as the children size increases.

\section{Multivariate test according to parent's educational level}

Table 5 shows the test of significant difference by parents' educational level across the three dependent variables. The $p$-value indicates that there is no significant difference between parents' educational level as regards self-efficacy beliefs, attitudes toward statistics, and performance in statistics. Thus, the parents' educational level had no significant effect on the success of the students.

Whether the parents are at the elementary, secondary or tertiary level does not matter with the students' self-efficacy beliefs. This contention means the student's selfefficacy beliefs do not regard the parents' educational level. It means that the parents' educational level does not play any role in showing that they are being anxious in managing 
mathematical problem-solving and tasks as well as their attitudes toward statistics. Furthermore, the parents' educational level does not influence the performance of students in statistics and probability. Therefore, the performance of the students in the subject itself does not differ with regards to their parents' educational level whether elementary, secondary or tertiary level or graduate. Thus, an inference that students have low performance regardless of the educational level of their parents is sound.

Vellymalay (2010) study dealt with the relationship between parents' education level and their immersion in their children's education. The inquiry revealed that there were no significant differences between parents' education level and parents' involvement plans for their children's education. The finding in the present study confirms the claim of

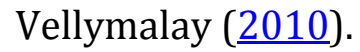

Table 5

Summary of MANOVA results across parent's educational level

\begin{tabular}{|c|c|c|c|c|c|c|c|}
\hline $\begin{array}{c}\text { Independent } \\
\text { Variables }\end{array}$ & Dependent Variables & $\begin{array}{l}\text { Type III Sum } \\
\text { of Squares }\end{array}$ & $\mathrm{df}$ & Mean Square & $\mathrm{F}$ & Sig. & $\begin{array}{l}\text { Partial Eta } \\
\text { Squared }\end{array}$ \\
\hline \multirow{3}{*}{$\begin{array}{l}\text { Corrected } \\
\text { Model }\end{array}$} & Self-Efficacy Beliefs & $0.169^{a}$ & 2 & 0.084 & 0.367 & 0.693 & 0.001 \\
\hline & $\begin{array}{l}\text { Attitudes toward } \\
\text { Statistics }\end{array}$ & $0.456^{\mathrm{b}}$ & 2 & 0.228 & 1.980 & 0.139 & 0.007 \\
\hline & $\begin{array}{l}\text { Performance in } \\
\text { Statistics }\end{array}$ & $49.503^{c}$ & 2 & 24.751 & 2.017 & 0.134 & 0.007 \\
\hline \multirow{3}{*}{ Intercept } & Self-Efficacy Beliefs & 3491.54 & 1 & 3491.54 & 15203.13 & 0.000 & 0.964 \\
\hline & $\begin{array}{c}\text { Attitudes toward } \\
\text { Statistics }\end{array}$ & 4309.71 & 1 & 4309.71 & 37435.23 & 0.000 & 0.985 \\
\hline & $\begin{array}{l}\text { Performance in } \\
\text { Statistics }\end{array}$ & 2473572.65 & 1 & 2473572.65 & 201621.49 & 0.000 & 0.997 \\
\hline \multirow{3}{*}{$\begin{array}{l}\text { Parent's } \\
\text { Educational } \\
\text { Level }\end{array}$} & Self-Efficacy Beliefs & 0.169 & 2 & 0.084 & .367 & 0.693 & 0.001 \\
\hline & $\begin{array}{c}\text { Attitudes toward } \\
\text { Statistics }\end{array}$ & 0.456 & 2 & 0.228 & 1.980 & 0.139 & 0.007 \\
\hline & $\begin{array}{l}\text { Performance in } \\
\text { Statistics }\end{array}$ & 49.50 & 2 & 24.751 & 2.017 & 0.134 & 0.007 \\
\hline \multirow{3}{*}{ Error } & Self-Efficacy Beliefs & 130.22 & 567 & 0.230 & & & \\
\hline & $\begin{array}{c}\text { Attitudes toward } \\
\text { Statistics }\end{array}$ & 65.28 & 567 & 0.115 & & & \\
\hline & $\begin{array}{l}\text { Performance in } \\
\text { Statistics }\end{array}$ & 6956.18 & 567 & 12.268 & & & \\
\hline \multirow{3}{*}{ Total } & Self-Efficacy Beliefs & 5170.78 & 570 & & & & \\
\hline & $\begin{array}{c}\text { Attitudes toward } \\
\text { Statistics }\end{array}$ & 6305.68 & 570 & & & & \\
\hline & $\begin{array}{c}\text { Performance in } \\
\text { Statistics }\end{array}$ & 3554902.00 & 570 & & & & \\
\hline
\end{tabular}

\section{Multivariate test according to SHS track preference}

Table 6 presents significant difference in self-efficacy beliefs, attitudes towards statistics, and performance in statistics when grouped according SHS track preference. The $\mathrm{p}$-values indicate that there is a significant difference between the SHS track preference and attitudes toward statistics and no significant difference between the self-efficacy beliefs and performance in statistics.

The multivariate test statistics makes it possible to conclude that the attitudes toward statistics and SHS track preference of the students differ significantly. This means that their attitudes toward statistics could be an indicator in choosing their track (ACAD or TVL) or strand in senior high school. It has an effect size of $0.9 \%$ of the variability across their 
preference. There is $0.0 \%$ of the variability in the SHS track preference across self-efficacy beliefs and performance in statistics.

Table 6

Summary of MANOVA results across SHS Track Preference

\begin{tabular}{|c|c|c|c|c|c|c|c|}
\hline $\begin{array}{c}\text { Independent } \\
\text { Variables }\end{array}$ & Dependent Variables & $\begin{array}{l}\text { Type III Sum } \\
\text { of Squares }\end{array}$ & df & Mean Square & $\mathrm{F}$ & Sig. & $\begin{array}{l}\text { Partial Eta } \\
\text { Squared }\end{array}$ \\
\hline \multirow{3}{*}{$\begin{array}{l}\text { Corrected } \\
\text { Model }\end{array}$} & Self-Efficacy Beliefs & $0.027^{a}$ & 1 & .027 & .117 & .732 & .000 \\
\hline & $\begin{array}{l}\text { Attitudes toward } \\
\text { Statistics }\end{array}$ & $1.781^{b}$ & 1 & 1.781 & 15.820 & .000 & .027 \\
\hline & $\begin{array}{l}\text { Performance in } \\
\text { Statistics }\end{array}$ & $37.818^{c}$ & 1 & 37.818 & 3.083 & .080 & .005 \\
\hline \multirow{3}{*}{ Intercept } & Self-Efficacy Beliefs & 5011.32 & 1 & 5011.32 & 21835.41 & .000 & .975 \\
\hline & $\begin{array}{l}\text { Attitudes toward } \\
\text { Statistics }\end{array}$ & 6190.58 & 1 & 6190.58 & 54984.14 & .000 & .990 \\
\hline & $\begin{array}{l}\text { Performance in } \\
\text { Statistics }\end{array}$ & 3526931.33 & 1 & 3526931.33 & 287505.08 & .000 & .998 \\
\hline \multirow{3}{*}{$\begin{array}{l}\text { SHS Track } \\
\text { Preference }\end{array}$} & Self-Efficacy Beliefs & 0.027 & 1 & .027 & .117 & .732 & .000 \\
\hline & $\begin{array}{l}\text { Attitudes toward } \\
\text { Statistics }\end{array}$ & 1.781 & 1 & 1.781 & 15.820 & .000 & .027 \\
\hline & $\begin{array}{l}\text { Performance in } \\
\text { Statistics }\end{array}$ & 37.82 & 1 & 37.818 & 3.083 & .080 & .005 \\
\hline \multirow{3}{*}{ Error } & Self-Efficacy Beliefs & 130.34 & 568 & .230 & & & \\
\hline & $\begin{array}{l}\text { Attitudes toward } \\
\text { Statistics }\end{array}$ & 63.95 & 568 & .113 & & & \\
\hline & $\begin{array}{l}\text { Performance in } \\
\text { Statistics }\end{array}$ & 6967.87 & 568 & 12.267 & & & \\
\hline \multirow{3}{*}{ Total } & Self-Efficacy Beliefs & 5170.78 & 570 & & & & \\
\hline & $\begin{array}{l}\text { Attitudes toward } \\
\text { Statistics }\end{array}$ & 6305.68 & 570 & & & & \\
\hline & $\begin{array}{l}\text { Performance in } \\
\text { Statistics }\end{array}$ & 3554902.00 & 570 & & & & \\
\hline
\end{tabular}

Furthermore, the performance of students in statistics and probability as to the SHS track taken is not significant. This figure means that the performance of the students does not differ based on whether they choose the Academic Track (ACAD) or Technology Vocational Livelihood track (TVL). The students, therefore, have low performance regardless of the SHS track taken or preferences. The result substantiates Braza and Gillo (2015) claim that numerous factors influence most students' career choices. These are outcome expectancies, individual variants such as sex, personal interests, learning experiences, environmental factors, and personal contacts. Similarly, the same result supports the study that the factors influencing the senior high school students' educational and career choice are the parental support, school structure, gender, and grade point average.

\section{Multivariate test according to type of school}

Table 7 shows the test of significant difference by the type of school across the three dependent variables. The $p$-values indicate that there is a significant difference between the type of school regarding self-efficacy beliefs, attitudes toward statistics, and performance in statistics. The results mean that the type of school has a significant influence on the success of the students. Moreover, public secondary school students perform better than private school students in solving statistical problems. 
Table 7

Summary of MANOVA results across type of school

\begin{tabular}{|c|c|c|c|c|c|c|c|}
\hline $\begin{array}{l}\text { Independent } \\
\text { Variables } \\
\end{array}$ & Dependent Variables & $\begin{array}{c}\text { Type III Sum } \\
\text { of Squares }\end{array}$ & $\mathrm{df}$ & Mean Square & $\mathrm{F}$ & Sig. & $\begin{array}{c}\text { Partial Eta } \\
\text { Squared }\end{array}$ \\
\hline \multirow{3}{*}{$\begin{array}{l}\text { Corrected } \\
\text { Model }\end{array}$} & Self-Efficacy Beliefs & $0.957^{\mathrm{a}}$ & 1 & 0.957 & 4.198 & 0.041 & 0.007 \\
\hline & $\begin{array}{l}\text { Attitudes toward } \\
\text { Statistics }\end{array}$ & $1.238^{\mathrm{b}}$ & 1 & 1.238 & 10.906 & 0.001 & 0.019 \\
\hline & $\begin{array}{l}\text { Performance in } \\
\text { Statistics }\end{array}$ & $792.369 c$ & 1 & 792.369 & 72.436 & 0.000 & 0.113 \\
\hline \multirow{3}{*}{ Intercept } & Self-Efficacy Beliefs & 4999.09 & 1 & 4999.09 & 21938.610 & 0.000 & 0.975 \\
\hline & $\begin{array}{l}\text { Attitudes toward } \\
\text { Statistics }\end{array}$ & 6189.22 & 1 & 6189.22 & 54509.40 & 0.000 & 0.990 \\
\hline & $\begin{array}{l}\text { Performance in } \\
\text { Statistics }\end{array}$ & 3497492.89 & 1 & 3497492.89 & 319728.83 & 0.000 & 0.998 \\
\hline \multirow{3}{*}{$\begin{array}{l}\text { Type of } \\
\text { School }\end{array}$} & Self-Efficacy Beliefs & 0.957 & 1 & 0.957 & 4.198 & 0.041 & 0.007 \\
\hline & $\begin{array}{l}\text { Attitudes toward } \\
\text { Statistics }\end{array}$ & 1.238 & 1 & 1.238 & 10.906 & 0.001 & 0.019 \\
\hline & $\begin{array}{l}\text { Performance in } \\
\text { Statistics }\end{array}$ & 792.37 & 1 & 792.369 & 72.436 & 0.000 & 0.113 \\
\hline \multirow{3}{*}{ Error } & Self-Efficacy Beliefs & 129.43 & 568 & .228 & & & \\
\hline & $\begin{array}{l}\text { Attitudes toward } \\
\text { Statistics }\end{array}$ & 64.49 & 568 & .114 & & & \\
\hline & $\begin{array}{l}\text { Performance in } \\
\text { Statistics }\end{array}$ & 6213.32 & 568 & 10.939 & & & \\
\hline \multirow{3}{*}{ Total } & Self-Efficacy Beliefs & 5170.78 & 570 & & & & \\
\hline & $\begin{array}{l}\text { Attitudes toward } \\
\text { Statistics }\end{array}$ & 6305.68 & 570 & & & & \\
\hline & $\begin{array}{c}\text { Performance in } \\
\text { Statistics }\end{array}$ & 3554902.00 & 570 & & & & \\
\hline
\end{tabular}

According to Philias and Wanjobi (2011), school type has some impact on student academic performance. The latter emphasized its impact on statistics performance. Moreover, a study conducted by Thapa $(\underline{2015})$ found that private school students perform better than public school students in solving mathematical problems. This result agrees with the finding of Callaman and Itaas (2020) that the type of school had a significant relationship on a student's academic performance. The availability of school facilities and the school environment came out as determining factors.

\section{Multivariate analysis on self-efficacy beliefs, attitudes, and performance}

The Box's M test and Levene's test reveal that there is no significant difference between the covariance matrices and the matrices are equal. Therefore, the assumption for homogeneity is met. Since there is no violation in the assumption, Wilk's Lambda is an appropriate test to use.

The MANOVA Table used Wilk's Lambda test. Table 8 shows that gender is not significant, Wilk's Lambda $=0.986, \mathrm{~F}(3,441)=2.102, \mathrm{p}>.001$, multivariate $\eta^{2}=0.014$. The value of $\mathrm{F}$ is not significant indicating that there are no significant differences among the gender (male or female) groups on the three dependent variables.

Based on the multivariate effects across all three dependent variables, the type of school whether public or private secondary schools is a significant factor. It causes the variations of the effect sizes in the student performance, self-efficacy and attitudes towards statistics. The type of school then affects the performance of the students. This fact further 
conforms to what Callaman (2018) mentioned that the type of school has a significant relationship to students' academic performance.

Table 8

Multivariate effects of demographic profiles

\begin{tabular}{ccccccc}
\hline $\begin{array}{c}\text { Independent } \\
\text { Variables }\end{array}$ & $\begin{array}{c}\text { Wilks' } \\
\text { Lambda }\end{array}$ & $\mathrm{F}$ & $\begin{array}{c}\text { Hypothesis } \\
\mathrm{df}\end{array}$ & Error df & Sig. & $\begin{array}{c}\text { Partial Eta } \\
\text { Squared }\end{array}$ \\
\hline Gender & 0.986 & 2.090 & 3 & 441 & 0.101 & 0.014 \\
$\begin{array}{c}\text { Family Size } \\
\text { Family }\end{array}$ & 0.997 & 0.214 & 6 & 882 & 0.972 & 0.001 \\
$\begin{array}{c}\text { Monthly } \\
\text { Income }\end{array}$ & 0.996 & 0.308 & 6 & 882 & 0.933 & 0.002 \\
$\begin{array}{c}\text { Parent's } \\
\text { Educational } \\
\text { Level }\end{array}$ & 0.989 & 0.828 & 6 & 882 & 0.548 & 0.006 \\
$\begin{array}{c}\text { SHS Track } \\
\text { Preference } \\
\text { Type of } \\
\text { School }\end{array}$ & 0.988 & 1.819 & 3 & 441 & 0.143 & 0.012 \\
\hline
\end{tabular}

This finding implies that the type of school where the learner studies significantly affect his/her academic performance. The impact of the type of school whether private or public plays a vital role in determining the achievement in statistics, self-efficacy, and attitudes toward statistics. Moreover, as Callaman and Itaas (2020) articulated, attitudes toward mathematics also affect mathematics achievement negatively. This result may be due to the notion of students that the subject is difficult, complicated and unattractive; and teachers are perceived as strict when it comes to teaching. These states of mind lead to a negative effect on the performance of the students as well. Moreover, Callaman and Itaas (2020) stressed that mathematical skills, self-efficacy, and students' attitude positively influence mathematics performance and varies according to the type of school. Furthermore, the studies of Thapa $(\underline{2015})$ which revealed that the type of school has significant effect on the academic performance of the students, thus, private school students perform better than public school.

\section{Conclusion}

Based on the findings of this study, the following conclusions are drawn. First, since the level of student's self-efficacy beliefs and attitudes towards statistics is neither agree nor disagree, the students cannot make a clear-cut decision whether they are favorable or not with the statements on self-efficacy and the students have an uncertain opinion whether they dislike or like statistics. Level of student's performance in statistics is fairly satisfactory, this implies that most of the students possess the minimum knowledge and skills and core understanding in statistics but need help throughout the performance of tasks. Second, the variables such gender, family income, family size, parents' educational level, and SHS track preference do not affect the students' self-efficacy, attitudes toward mathematics, and their performance in mathematics, while the type of school does. Third, since the type of school is a key determinant of student's self-efficacy, attitudes towards statistics and performance in statistics, thus, class size and facilities, as well as other factors that substantially differentiate private from public schools, significantly affect the dependent variables. Lastly, due to the limited studies in Mindanao, future studies may take into consideration to include the schools in the rural areas in the sampling to provide and establish strong statistical analysis and solid evidence of the factors that influence the 
determinants significantly affect the performance of senior high school students in statistics. Further research should be done in order to confirm or refute the findings of this study.

\section{Acknowledgment}

The researchers would like to express their heartfelt gratitude to all the people who have contributed to the success of this research endeavor especially to their family, friends, and colleagues.

\section{Bibliography}

Ajai, J. T., \& Imoko, I. I. (2015). Gender differences in Statistics achievement and retention scores: A case of problem-based learning method. International Journal research in Education and Science (IJRES), I(1), 45-50.

Ali, H. O. (2013). Factors affecting students' academic performance in Mathematical Sciences Department in tertiary institutions in Nigeria. US-China Education Review A, 3(12), 905-913.

Arghode, V. (2012). Qualitative and quantitative research: Paradigmatic differences. Global Education Journal, 2012(4), 155-163. Retrieved from https://eds.a.ebscohost.com.library.gcu.edu:2048/ehost/

Asante, K. O. (2012). Secondary students' attitudes towards Statistics. IFE Psycologia: An International Journal 20(1), 121-133. Retrieved form https://journals.co.za/doi/abs/10.10520/EJC38916

Baksh Ali, Z. S., Pasaha, E. \& Rastegar, A. (2013). Statistics and modeling. Tehran: Iranina textbook Publishing Company.

Bandura, A. (1986). Social Foundations of Thought and Action: A Social Cognitive Theory. Englewood Cliffs, N.J. Prentice Hall.

Batanero, C. \& Diaz, C. (2010). Training teachers to teach statistic:what can we learn from research? Statistique et enseignement, 1(1), 5-20.

Boone, H. N., \& Boone, D. A. (2012). Analyzing likert data. Journal of extension, 50(2), 1 - 5.

Braza, M. r. \& Guillo, Jr. R. M. (2015). Socio-demographic characteristics and career choice of private secondary school students. Asia pacific Journal of Multidisciplinary Research, Vol. 3, No. 4.

Byrne, M., Flood, B., \& Griffin, J. (2014). Measuring the academic self-efficacy of first-year accounting students. Accounting Education,23(5), 407-423. Retrieved from https://www.tandfonline.com/doi/abs/10.1080/09639284.2014.931240

Callaman, R. A. \& Itaas, E. C. (2020). Students' Statistics achievement in Mindanao context: A meta-analysis. JRAMathEdu Journal of Research and Advances in Statistics Education), 5(2), 148-159. Retrieved from https://files.eric.ed.gov/fulltext/E]1267489.pdf

Chapagain, Y. (2021). School student academic performance in Nepal: An analysis using the School Education Exam (SEE) results. International Journal on Studies in Education, 3(1), 22-36. https://doi.org/10.46328/ijonse.34

Chiesi, F., Pirmi. C., \& Morsanyi, K. (2010). Learning Probability and Statistics:Cognitive and Non-cognitive Factors Related to Psychology Students' Achievement. International Association of Statistical Education (ISAE).

Chinn, S. (2012). Beliefs, anxiety and avoiding fear in Statistics. Child Development Research, 2012. 
Department of Education Order No. 8s. (2015). Policy Guidelines on Classroom Assessment for the K to 12 Basic Education Program. Retrieved from PISA 2018 National Report of the Philippines.

Doyle, K. M., Dias, O., Kennis, J. R., Czarnocha, B. \& Baker, W. (2015). The ratonal number subconstructs as a foundation for problem solving. Adults Learning Statistics: An International Journal, 11(1), 21-42. Retrieved from https://files.eric.ed.gov/fulltext/EJ1091996.pdf

Emmioglu, E., \& Capa-Aydin, Y. (2012). Attitudes and achievement in statistics: A metaanalysis study. Statistics Education Research Journal, 11(2) 95 - 102.

Gherasim, L. R., Butnaru. S., \& Mairean, C. (2013). Classroom environment, achievement goals and maths performance: gender differences. Educational Studies, 39(1),1 -12.

Gray, L. R., Mills, G. E., \& Airasian, P. (2011). Educational research: Competencies for analysis and application. (10th ed.), Upper Saddle River, NJ: Pearson.

Hansen, R. \& Myers, J. (2012). Rote versus conceptual emphases in teaching elementary probability. Journal for $R$ (Placeholder1) Research Statistics Education, 16, 364-374. https://doi.org/10.5951/jresematheduc.16.5.0364

Herrera, F. (2011). Problem and activity-based approaches: Their influences to student's achievement and retention scores in introductory probability and statistics. International Association of Multidisciplinary Research Journal, 2(1), 48-67. Retrieved from https://ejournals.ph/article,php?id=2425

Humlum, M. (2011). Timing of family income, borrowing constraints and child achievement. Journal of Population Economics, vol. 24, 3, 979-1004.

Huynh, M., Baglin, J., \& Bedford, A. (2014). Improving the attitudes of high school students towards statistics: An island-based approach. In Sustainability in Statistics Education. Proceedingd of the Ninth International Conference on Teaching Statistics (ICOTS9), Flagstaff, Arizona, USA. Voorburg; International Association of Statistics Association> Retrieved from https://icots.info/9/proceedings/pdfs/ICOTS99G@ HUYNH.pdf

Hussain, Dr. (2019). Re: How does causal-comparative research designs fit to Information systems science?

Jamisola, N. B. (2014). Predictors of Statistics Performance of Fourth Year Students in Davao City [Unpublished Thesis]. University of Southeastern Philippines, Davao City, Philippines.

Lacovou, M. (2010). Leaving home: Independence, togetherness and income. Institute for Social and Economic Research, Essex University, Colchester CO4 3SQ, UK.

Lemana, L. G. (2012). A Structural Model Predicting Performance of Freshmen Statistics Unpublished Thesis. University of Southeastern Philippines, Davao City, Philippines.

McGrath, A. L., Ferns, A., Greiner, L., Wanamaker, K., \& Brown, S. (2015). Reducing anxiety and increasing self-efficacy within an advanced graduate psychology statistics course. Canadian Journal for the Scholarship of Teaching and Learning, 6(1), 5. Retrieved from https://eric.ed.gov/?id=EJ1057728

Murray, S. (2011). Declining participation in post-compulsory secondary school Statistics: students' views and solutions to the problem. Research in Statistics Education, 13(3), 269-285. https://doi.org/10.1080/14794802.2011.624731

Orongan, R. C. (2007). Structural model of cognitive, affective and demographic factors on tertiary student's performance in introductory statistical at Central Mindanao University, Bukidnon Philippines. [Unpublished Dissertation]. Central Mindanao Univeristy, Bukidnon Philippines. 
Parker, P. D., Marsh, H. W., Ciarrochi, J., Marshall, S., \& Abduljabbar, A. S. (2013). Juxtaposing math self-efficacy and self-concept as predictors of long-term achievement outcomes. Educational Psychology, 34(1), 29-48.

Peters, P., Smith, A., Middledorp, J., Karpin, A., Sin, S., \& Kilgore, A. (2013). Learning essential terms and concepts in statistics and accounting. Higher Education Research \& Development, 33(4), 742 - 756. https://doi.org/10.1080/07294360.2013.863838

Philias, O. Y., \& Wanobi, W. C. (2011). Performance determinants of Kenya Certificate of Secondary Education (KCSE) in Statistics of secondary schools in Nyamaiya Division, Kenya. Asian Social Science, 7 (2), 107-112.

Prado, M. \& Gravoso, R. (2011). Improving high school students' statistical reasoning skills: A case of applying anchored instruction. The Asia-Pacific Education Researcher, 20(1), $61-72$.

Reardon, S. F. (2013). The widening income achievement gap. Educational leadership, 70(8), 10-16.

Salvan, N. L. (2014). Determinants of Grade 7 Mathematical Achievement: Basis for Developing a Tool for Selecting Special Program of the Science, Technology and Engineering (STE) Students [Unpublished master's thesis]. University of Southeastern Philippines, Davao City, Philippines

Salvan, E. (2016). Demographic Characteristics, Socio-Psychological Attributes, and Performance of College Students in Statistics. [Unpublished Dissertation]. Central Mindanao University, Bukidnon Philippines.

Schneider, W. R. (2011). The relationship between statistics self-efficacy, statistics anxiety, and performance in an introductory graduate statistics course. Retrieved from https://scholarcommons.usf.edu/etd/3335

Swift, J. (2012). Challenges for enriching the curriculum: Statistics and probability. Statistics Teachers, 76, 268 - 269. https://doi.org/10.5951/MT.76.4.0268

Thapa, A. (2015). Public and private school performance in Nepal: an analysis using the SLC examination. Education Economics, 23(1), 47-62. Retrieved from https://www.tandfonline.com/doi/abs/10.1080/09645292.2012.738809

Vellymalay, S.K.N. (2010). Parental involvement in children's education: Does parents' education level really matter? European Journal of Social Sciences,16(3), 430-431.

Williams, A. (2014). An exploration of preference for numerical information in relation to math self-concept and statistics anxiety in a graduate statistics course. Journal of Statistics Education, 2(1), 1-16. Retrieved from https://eric.ed.gov/?id=EJ1031923

Yilmaz, K. (2013). Comparison of quantitative and qualitative research traditions: Epistemological, theoretical, and methodological differences. European Journal of Education, 48(2), pp. 311-325.

Zacal, S. G. (2019). Psycho-social Attributes, Reading Comprehension and Problem-Solving Skills of Junior High School: A Structural Model on Statistics Performance [Unpublished Dissertation]. Bukidnon State University, Malaybalay City, Bukidnon, Philippines.

Zieffler, A., Garfield, J., Alt, S., Dupuis, D., Holleque, K., \& Chang, B. (2008). What Does Research Suggest About the Teaching and Learning of Introductory Statistics at the College Level? A Review of the Literature. Journal of Statistics Education, 16(2). Retrieved from https://jse.amstat.org/v16n2/zieffler.pdf 